\title{
BIOSTRATIGRAPHIC AND BIOGEOGRAPHIC IMPLICATIONS OF MIOCENE MAMMALS FROM JACKSON HOLE, WYOMING
}

\author{
A. D. Barnosky \\ Department of Geological Sciences \\ University of Washington
}

\section{Objectives}

Under the auspices of the U. S. Geological Survey and the University of Washington, detailed investigations of Miocene vertebrates and sediments in Jackson Hole, Wyoming commenced in 1979. Principal objectives of this research include:

1. Documenting the occurrence of mid-Tertiary mammals from Jackson Hole. Although fossils have been reported from Miocene rocks in the region (Love, 1956; Sutton and Black, 1972), existing collections are small.

2. Biostratigraphic correlation of isolated vertebrate localities throughout the northern Rocky Mountains with the superimposed localities in and near Grand Teton National Park. Such correlation will help determine whether regional or local tectonic events caused downwarping of Jackson Hole and uplift of the Teton Range.

3. Clarifying geographic variation of some small mammals through long periods of geologic time by comparison of West Coast (Rensberger, 1971, 1973; Martin, 1979), Great Plains (Macdonald, 1963, 1970; Galbreath, 1953; Wilson, 1960), and the newly collected Jackson Hole faunas.

This report summarizes accomplishments of the 1980 field season. Approximately one more season of field work and an ensuing year of data analysis are required before a final report will be available.

\section{Methods}

Areas prospected for fossils during 1980 incluaed the northwest shore of Two Ocean Lake, the "crater" approximately one mile north of Two Ocean Lake, the northernmost exposures along Pilgrim Creek, and outcrops near the headwaters of Fox Creek (locality SR, Love et a1, 1976) in the Teton Wilderness Area. All outcrops were walked at three-meter contour intervals to locate small bone fragments. To test for vertebrate microfossils, at least $200 \mathrm{lbs}$. ( $90 \mathrm{~kg}$.) of matrix were screen-washed at each locality where bone fragments were evident. 
Fossil sites discovered in 1979, and some described by Sutton and Black (1972) and Love (1956), were extensively worked in 1980. These included localities along P1lgrim Creek and Cunningham H111 (Colter Formation), the Dipoides Quarry (Teewinot Formation) east of Gros Ventre Junction in Grand Teton National Park, and the Boyle's Ditch section (formation not named) on the National Elk Refuge. Localities in the Colter Formation and Boyle's Ditch section were worked by screen methods. Approximately 5000 lbs. $(2270 \mathrm{~kg}$.) of rock from each of these sites were concentrated into a fossil-rich matrix. The larger fossils from the Teewinot Formation were collected mainly by quarrying. Matrix from the quarry was further disaggregated by an acid bath and screened to recover microfossils.

\section{Results}

Vertebrate fossils were present at newly-prospected localities on northernmost Pilgrim Creek and Fox Creek. Oligocene rodents, rabbits, carnivores, horses, and artiodactyls were recovered. A few bone fragments found in the screened matrix from Fox Creek suggest the presence of a new Miocene (?) site. The majority of this matrix will be sorted during the winter.

The Dipoides Quarry yielded several hundred bones. Among the remains identifiable to species level are beavers (castorids), voles (microtines), mice (cricetines), and shrews (soricids). Fossils from this site now comprise one of the largest known collections of small mammals of latest Miocene age from the northern Rocky Mountains. The mammals are associated with abundant fossil reptiles, amphibians, molluscs, and possibly pollen.

The matrix concentrated from sites in the Colter Formation has yet to be sorted for identifiable fossils. Preliminary testing suggests that these localities will yield at least 200 to 300 teeth of small mammals. Pocket gophers (geomyids), pocket mice (heteromyids), mountain beavers (aplodontids), squirrels (sciurids), shrews (soricids), and rabbits (lagomorphs) are present. Large mammals such as camels (camelids), horses (equids), and oreodonts are also represented. Matrix from the Boyle's Ditch section has yielded some bones of small mammals, but will not be sorted until later this winter.

\section{Conclusions}

At least five superimposed vertebrate faunas are present in Jackson Hole. These faunas range in age from earliest to latest Miocene, and are located between 01 igocene and post-Miocene deposits. The oldest Miocene faunas are probably in the Teton Wilderness area near Fox Creek, and the youngest are from the Dipoides quarry. The latter is overlain by the Boyle's Ditch deposits, and Oligocene vertebrates underlie the Miocene rocks near Fox Creek and near the upper reaches of Pilgrim Creek. The fossils recovered this year should provide a large enough sample on which to base some biostratigraphic and biogeographic conclusions. These conclusions will be available after lab processing is completed. 


\section{Literature Cited}

Galbreath, E. C. 1953. A contribution to the Tertiary geology and paleontology of northeastern Colorado. Univ. Kansas Pal. Contrib., Vertebrata, no. 4. 120 pp.

Love, J. D. 1956. New formation names, Jackson Hole, Wyoming. Bull. Amer. Assoc. Pet. Geo1. 40(8):1899-1914.

Love, J. D., M. C. McKenna and M. R. Dawson. 1976. Eocene, 0ligocene, and Miocene rocks and vertebrate fossils at the Emerald Lake Locality, 3 miles south of Yellowstone National Park, Wyoming. U. S. Geological Survey Prof. Pap. 932-A. 28 pp.

Macdonald, J. R. 1963. The Miocene faunas from the Wounded Knee area of western South Dakota. Bull. Amer. Mus. Nat. Hist., 125:143-238.

Macdonald, J. R. 1970. Review of the Miocene Wounded Knee faunas of southwestern South Dakota. Bull. Los Angeles Co. Mus. Nat. Hist. Sci., no. 8. 82 pp.

Martin, J. E. 1979. Hemphillian rodents from northeastern Oregon and their relationships to other rodent faunas in North America. Doctoral Dissertation, University of Washington. 265 pp.

Rensberger, J. M. 1971. Entoptychine pocket gophers (Mammalia, Geomyoidea) of the early Miocene John Day Formation, Oregon. Univ. Cal. Pub1. Geol. Sci., no. 90. 209 pp.

Rensberger, J. M. 1973. Pleurolicine rodents (Geomyoidea) of the John Day Formation, Oregon, and their relationships to taxa from the early and middle Miocene, South Dakota. Univ. Cal. Publ. Geol. Sci., no. 102. 108 pp.

Sutton, J. F. and C. C. Black. 1972. Oligocene and Miocene deposits of Jackson Hole, Wyoming. In West (Ed.), Guidebook for Field Conference on Tertiary Biostratigraphy of Southern and Western Wyoming. Soc. Vert. Paleo.

Wilson, R. W. 1960. Early Miocene rodents and insectivores from northeastern Colorado. Univ. Kansas Pal. Contrib., Vertebrata, no. 7. $92 \mathrm{pp}$.

\section{Acknowledgments}

For granting permission to work on federal lands this season, I thank the following individuals and agencies: Bob Wood, Grand Teton National Park Service; Joe Kinsella (Gros Ventre District) and Mac Murdock (Black Rock District), U. S. Forest Service; and John Wilbrecht, National E1k Refuge. The UW-NPS Research Center under the direction of Dr. Kenneth Diem generously provided living accomodations and research 
space. Harold Turner of the Triangle X Ranch arranged excellent packers' service. Funding for this field season was partially provided by Sigma Xi, the Corporation Fund of the Department of Geological Sciences, University of Washington, and the U. S. Geological Survey. 